Jean Baudrillard

Selected Writings 



\section{Jean Baudrillard}

Selected Writings

Second edition, revised and expanded

Edited and introduced by

Mark Poster

Stanford University Press

Stanford, California 
Stanford University Press

Stanford, California

(C) 2001 by the Board of Trustees of the Leland Stanford Junior University

Originating publisher of the English edition:

Polity Press in association with Blackwell Publishers Ltd.

Cloth ISBN 0-8047-4272-3

Paper ISBN 0-8047-4273-1

A catalog record for this book has been applied for from the Library of Congress.

First edition published 1988

Last figure below indicates the year of this printing:

1514131211

Typeset in 10.5 on 12 pt Sabon

by Kolam Information Services Pvt. Ltd, Pondicherry, India.

This book is printed on acid-free paper. 